\title{
Effects of synchronized and asynchronized e-feedback interactions on academic writing, achievement motivation and critical thinking
}

\author{
Mahmoud Mohamed Hussien Ahmed \\ Tokyo University of Agriculture and Technology, Japan \\ South Valley University, Egypt \\ Patricia S. McGahan \\ Tokyo University of Agriculture and Technology, Japan \\ Bipin Indurkhya \\ Jagiellonian University, Poland \\ Keiichi Kaneko \\ Masaki Nakagawa \\ Tokyo University of Agriculture and Technology, Japan
}

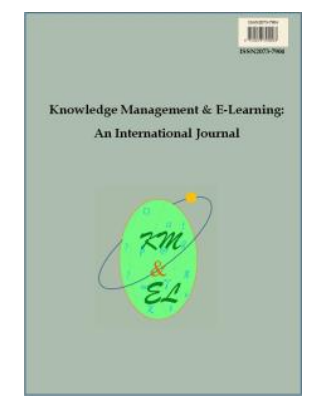

Knowledge Management \& E-Learning: An International Journal (KM\&EL) ISSN 2073-7904

Recommended citation:

Ahmed, M. M. H., McGahan, P. S., Indurkhya, B., Kaneko, K., \& Nakagawa, M. (2021). Effects of synchronized and asynchronized efeedback interactions on academic writing, achievement motivation and critical thinking. Knowledge Management \& E-Learning, 13(3), 290-315. https://doi.org/10.34105/j.kmel.2021.13.016 


\title{
Effects of synchronized and asynchronized e-feedback interactions on academic writing, achievement motivation and critical thinking
}

\author{
Mahmoud Mohamed Hussien Ahmed* (1) \\ Faculty of Engineering \\ Tokyo University of Agriculture and Technology, Japan \\ Faculty of Specific Education \\ South Valley University, Egypt \\ E-mail: mahmoud.ahmed@sed.svu.edu.eg
}

\section{Patricia S. McGahan}

Tokyo University of Agriculture and Technology, Japan

E-mail: pmcgahan@cc.tuat.ac.jp

\section{Bipin Indurkhya}

Institute of Philosophy

Jagiellonian University, Poland

E-mail: bipin.indurkhya@uj.edu.pl

\section{Keiichi Kaneko}

Faculty of Engineering

Tokyo University of Agriculture and Technology, Japan

E-mail: k1kaneko@cc.tuat.ac.jp

\section{Masaki Nakagawa}

Tokyo University of Agriculture and Technology, Japan

E-mail: nakagawa@cc.tuat.ac.jp

*Corresponding author

\begin{abstract}
We conducted a comparative study to evaluate the efficacy of synchronous and asynchronous interaction modes when providing feedback for improving academic writing, achievement motivation and critical thinking. The participants undertook an academic writing task, and were given feedback by a mentor using one of three interaction modes: asynchronous, synchronous efeedback, and face to face. Data was collected from the participants via an assessment rubric applied to their writing after each stage of interaction, along with pretest and posttest questionnaires, and a semi-structured interview at the end. We found that synchronous feedback is more effective in increasing the quality of academic writing and achievement motivation, but for critical thinking we did not find any significant difference. We suggest that a strategy
\end{abstract}


combining the advantages of each mode of interaction, considering the writers' experience, may be the most effective way to promote academic writing, achievement motivation and critical thinking.

Keywords: Asynchronized e-feedback interaction; Synchronized e-feedback interaction; Face-to-face interaction; Assessment rubrics; Supporting academic writing

Biographical notes: Mahmoud Mohamed Hussien Ahmed (Ph.D.) is an assistant professor in the Instructional Technology Department at South Valley University (SVU), Egypt. He received his Ph.D. as a joint supervision project from SVU and Kochi University of Technology, Japan. He was awarded a research fellowship at Tokyo University of Agriculture and Technology, Japan. $\mathrm{He}$ has been involved in multiple research projects in virtual learning environments, hybrid and flipped classrooms, enhancing equity, self-regulated learning, cognitive holding power, mindfulness-based mobile applications, and attention-regulation processes. He has participated in a number of international conferences including IDHF 2016, CHI 2017, mLearn 2020, and ICCE-2020. His research has been published in a variety of journals including Heliyon, iJET, Neuroscience and Biomedical Engineering.

Patricia McGahan, educator at Tokyo University of Agricultural and Technology, Japan, is involved with teaching research writing and presenting, along with global awareness, while adapting creativity in Life Sciences and Biotechnology, Applied Chemistry, Chemical Systems Engineering, Mechanical Systems Engineering, Applied Physics and Information Sciences. Patricia has a bachelor's degree in International Relations from California State University, Chico, USA and has done master's studies in education through Temple University. Currently she is pursuing a $\mathrm{PhD}$ in a Joint Doctoral Program for Sustainability Research with a focus on sustainability science, sustainability literacy assessment, and engagement.

Bipin Indurkhya is a professor of Cognitive Science at Jagiellonian University, Krakow, Poland. His main research interests are social robotics, usability engineering, affective computing and creativity. He received his Master's degree in Electronics Engineering from the Philips International Institute, Eindhoven (The Netherlands) in 1981, and $\mathrm{PhD}$ in Computer Science from University of Massachusetts Amherst in 1985. He has taught at various universities in the US, Japan, India, Germany and Poland; and has led national and international research projects with collaborations from companies like Xerox and Samsung.

Keiichi Kaneko (Member, IEEE) received B.E., M.E., and Ph.D. (Eng.) degrees from The University of Tokyo, in 1985, 1987, and 1994, respectively. He is currently a Professor with Tokyo University of Agriculture and Technology, Japan. His main research interests include functional programming, parallel and distributed computation, partial evaluation, fault-tolerant systems, and pedagogical systems. He is a member of ACM, IEEE CS, IEICE, IPSJ, and JSSST.

Masaki Nakagawa was born on 31 Oct. 1954. He received his B.Sc. and M.Sc. degrees from The Univ. of Tokyo in 1977 and 1979, respectively. During the academic year 1977/78, he enrolled in the Computer Science course at Essex Univ. in England and received a M.Sc. with distinction in Computer Studies in July 1979. He received his Ph.D. from the Univ. of Tokyo in Dec. 1988. He has been working at TUAT since April 1979. He is currently a Vice-President at TUAT. 


\section{Introduction}

University students and researchers need to improve their academic writing skills to prepare technical reports, write research proposals, apply for scientific scholarships, and publish their scientific results in conference proceedings and journals. Feedback on writing is the comments, questions, and suggestions from a reviewer to a writer for improving the quality of the writing (Keh, 1990). The reviewer can be a professor who is an expert co-author, or an English language reviewer and the writer is a researcher who needs to write a scientific manuscript. Feedback interaction on academic writing refers to the way that the reviewer prepares and delivers the comments, questions, and suggestions on the written academic manuscript to the writer besides the way that the writer can receive, discuss, and ask for help about what he/she receives from the reviewer. The mentioned process can be enhanced within synchronous activities through Skype or asynchronous activities through email (electronic feedback) or traditional feedback through face-to-face meetings. One often faces pressure and feels stress when having to produce academic publications required for granting an academic degree or obtaining a scientific position (Herbert et al., 2014). People who are good researchers are not always good writers, and a majority of students face difficulty at various times when reporting about their research (Glasman-Deal, 2010). With an increasing use of IT in education that can be effectively employed to improve academic writing for university students and researchers. Also, it also provides both synchronous and asynchronous interaction applications that support collaborative academic writing and help the writer to receive feedback from senior researchers or professors.

The importance of improving university students and researchers' academic writing (Sachs, 2002), critical thinking skills (Zhang \& Toker, 2011; Borglin \& Fagerström, 2012; Hall, 2017) and achievement motivation (Chiang et al., 2014; Liao, Ferdenzi, \& Edlin, 2012), has been acknowledged. In addition, McClelland (2005) found that feedback is essential for academic achievement and e-feedback can also lead to improving learners' academic competencies. Although the importance of achievement motivation has been recognized, there are only a few studies on how it can be improved among university students and researchers (Zhang et al., 2015). Besides, there is little research on how different interaction synchronizations between a teacher and a student support the construction of arguments, which is applied in critical academic writing to enable students to edit their scientific documents. In particular, there is no study for distinguishing the efficacy of different e-feedback methods, which include face-to-face, synchronous and asynchronous interaction.

Therefore, the goal of our research is to obtain a deeper understanding of how different modes of feedback (synchronous and asynchronous e-feedback and traditional face-to-face feedback) affect the improvement of academic writing, achievement motivation and critical thinking among university students and researchers. Specifically, we seek to answer the following research questions:

1. How do modes of interaction (asynchronous e-feedback vs. synchronous efeedback vs. face-to-face feedback), affect the improvement of academic writing skills for university students and researchers?

2. How do modes of interaction (asynchronous e-feedback vs. synchronous efeedback vs. face-to-face feedback), affect the improvement of university students and researchers' motivation? 
3. How do modes of interaction (asynchronous e-feedback vs. synchronous efeedback vs. face-to-face feedback), affect the improvement of critical thinking skills for university students and researchers?

\section{Background and motivation}

\subsection{Synchronous and asynchronous e-feedback}

In synchronous e-feedback interaction, students and teachers interact in real time through digital technology. In asynchronous e-feedback interaction, after a teacher has given material and after a student has accessed material, completed and submitted an assignment, feedback is given in writing and the student accesses it at a different time. Each of these modes has pros and cons with respect to their effectiveness in learning. Abrams (2003) noted that both synchronous and asynchronous interactions enable more extensive students-teacher interactions and provide more time for discussion thereby leading to improved proficiency in language skills.

Synchronous e-feedback can support learning by creating a positive social experience and engaging learners in cooperative learning activities (Boling et al., 2012). It can also increase the learning output compared with asynchronous interactions because learners may take asynchronous learning activities less seriously (Abrams, 2003). Synchronous interaction decreases ambiguity with learning experiences because it provides immediate e-feedback. Synchronous systems yield better improvement of the learning motivation compared with asynchronous interactions (Hrastinski, 2008). Synchronous audio interaction helps teachers to provide direct instructions to the students to support quality learning, but requires finding a meeting time that is convenient both for the teacher and the student, thereby lacking flexibility, which may negatively affect the student's motivation toward learning activities. (Murphy et al., 2011). Thus, providing synchronous e-feedback seems more effective than asynchronous feedback for improving learning motivation.

Asynchronous interaction is less effective than face-to-face interaction in improving writing and the dropout rate is higher (Carpenter et al., 2004). However, asynchronous interactions compared with synchronous have a more positive effect on the long-term retention of the learning information (Roblyer et al., 2007). Asynchronous interactions lead to an increased reflection on the learning activities because they have better flexibility of scheduling and gives an opportunity for a prolonged individual interaction with the learning resources. Thus, although asynchronous e-feedback has some drawbacks, it can lead to improving long-term learning and enhancing reflection, thereby leading to improved achievement motivation.

Given this controversy, we chose to investigate how these two different modes of interaction affect the improvement of academic writing, critical thinking and achievement motivation for university students and researchers.

\subsection{Impact of feedback on students' achievement motivation}

Achievement motivation is a student's inner drive to desire and work to accomplish the learning goals. It has many dimensions such as the learner's willingness to expand their learning effort, a tendency to take a learning initiative, spend more time and effort in learning by combining engagement with flow, to become better and faster in learning, 
flexibility in accepting learning challenges, and to take the responsibility of learning without fail (Basaran \& Yalman, 2020; Lang \& Fries, 2006; Hermans, 1970). Achievement motivation is a criterion for the formation of critical thinking because it helps learners to exert more effort to search for the right solution for the problems, they are facing in learning activities (Averkieva et al., 2015; McClelland, 1961, p. 42).

Asynchronous written e-feedback helps students to invest their time and effort in studying the received feedback, and make a plan for improving their writing abilities. It can be suitable for solving the problem of individual differences among students and can engage students in their writing task (Waller \& Papi, 2017). Also, written comments (asynchronous interaction) can be provided as direct, indirect, explicit, or implicit feedback. Different types of feedback impact the accuracy of the writing efficiency and students' motivation differently (Papi et al., 2020). Sometimes, written corrective feedback is not preferred as it makes the student a passive recipient, which can lead to decreased motivation, rather than as an active participant in synchronous interactions mediated via online tools or face-to-face interaction (Hyland, 2011). Thus, asynchronous e-feedback can cater to individual differences among students, thereby improving their writing skills, but it may also lead to decreased student motivation.

On the other hand, using synchronous e-feedback in on-line writing sessions, compared with face-to-face interactions, helps students to achieve higher scores in constructing arguments, because in this kind of feedback the students' questions can be answered in real time. Also, synchronous interactions facilitate more discussion with the teacher, which provides opportunities to practice brainstorming, thereby leading to improved writing ability (Heift \& Caws, 2000). Thus, synchronous e-feedback helps in improving the students' critical thinking. Only a few studies have studied the effect of feedback timing on the improvement of achievement motivation among university students and researchers (Zhang et al., 2015), though the need for such a study was recognized awhile back by VandeWalle (2003). Our goal is to address this problem by investigating how synchronous and asynchronous e-feedback can improve university students and researchers' abilities on academic writing, achievement motivation, and critical thinking.

\subsection{Improving critical thinking through academic writing}

Critical thinking is a higher-order thinking skill that is essential to lifelong learning and to dealing effectively with a fast changing world. It is one of the required skills for university students and researchers in the $21^{\text {st }}$ century (Kong, 2014; Dwyer \& Walsh, 2020), and there is an interest for improving critical thinking among students of all ages (Alexander, 2014). It also includes assessment of the data, and linking new ideas and solutions with the students' prior knowledge. Critical thinking skills are also required in academic writing (Newman et al, 1997). Critical thinking is an intellectual process for generating ideas through applying, analyzing, and evaluating information. Editing written ideas with providing feedback is a technique for improving critical thinking (Muthmainnah, 2019). While practicing academic writing, the students should also generate new ideas, organize them, and construct convincing arguments. Critical thinking is an effective tool for improving and assessing students (Carter et al., 2017).

Although, academic writing and critical thinking are considered to be key objectives of students in higher education, and there is a need to enhance it among university students and researchers (Borglin \& Fagerström, 2012), still, there are many obstacles in achieving this objective (Borglin \& Fagerström, 2012; Sachs, 2002). Critical thinkers should be able to understand other viewpoints before reaching a conclusion 
(Thompson et al., 2003; Zhang \& Toker, 2011). Practicing critical thinking entails effective communication and problem-solving abilities that are used through the discussion amongst the researchers and the authors (Paul \& Elder, 2002). As the quality of communication for constructive discussion is a key factor, finding a suitable platform that provides feedback when the writer needs it and that gives adequate time for reflecting on the received feedback for solving the mistakes on academic writing, asking more details, adding valuable comments, and expressing writers' points of view related to the received feedback can help in improving critical thinking skills. Providing timely synchronous e-feedback often can increase the students critical thinking (Stein et al., 2013). Feedback is required in online learning, and is also key to improving critical thinking skills. Towards this goal, synchronous feedback can maintain students' motivation and keep them focused on learning from their mistakes (Tallent-Runnels et al., 2005). Immediate feedback can help the writer to concentrate on their writing problems and argue the reasons behind some written ideas. In addition, it can also lead to fruitful discussions related to the received feedback. Immediate feedback may help the writer to construct logical relations between their mistakes in writing and the methods of solving them.

Using asynchronous feedback within forums and chat software helps students to propose solutions and evaluate them critically. This improves their critical thinking (Kew \& Tasir, 2021; Chiang \& Fung, 2004). Also, both synchronous and asynchronous interactions can help in improving critical thinking, but it is necessary to provide students adequate time for reflecting on the feedback received. Osborne (2018) noted that using asynchronous discussion facilitates students' engagement and promotes their critical thinking. Asynchronous feedback supports improving critical thinking through providing adequate time for receiving, interpreting, reflecting on, searching for more details related to the received feedback. Writers when using asynchronous interaction can prepare the arguments and support their viewpoints and can also prepare more data for evaluating the received feedback that can help the writer to accept or reject the suggested feedback with strong evidence. As a result, asynchronous feedback can be a suitable interaction for improving writer' academic writing skills and motivation toward academic writing.

Synchronous interactions can also be used for improving critical thinking skills. Jacob (2012) noted that critical thinking skills in mathematics can be facilitated through problem-solving sessions in synchronous online discussion forums. We argue that such online forums can also be considered an asynchronous interaction. Moreover, the relationship between improving critical thinking in online discussion systems and academic achievement has not received much attention in literature; hence a detailed discussion is not possible (Jacob, 2012). However, the widespread and rapid shift to online teaching during the COVID-19 pandemic created unprecedented demand for turning to remote learning and using technology for improving learners' skills and knowledge (Carpenter, Krutka \& Kimmons, 2020; Weldon et al., 2021).

Critical thinking has many dimensions like induction, deduction, interpretation, and evaluation. Prior studies show that improving critical thinking requires more than four weeks of focused practice (Osborne et al., 2018), with discussions and debate to make the learning activities more interesting and engaging (Thompson et al., 2003). Although there is a positive correlation between improving academic writing and critical thinking, this connection needs to be further studied (Borglin \& Fagerström, 2012): there is a lack of studies that explore the improvement of university students' and researchers' critical thinking through academic writing (Preiss et al., 2013). Little is known about using synchronous interactions to support academic writing through online virtual space (Sun et al., 2017). The current study aims to fill this gap by investigating different effects 
of using synchronous and asynchronous feedback in improving critical thinking, academic writing, and how it may lead to support university students and researchers' achievement motivation.

\section{Method}

A quasi-experimental research design was used to study how different modes of efeedback - synchronous (audio feedback through Skype meetings combined with MS Word comments) and asynchronous (text feedback through email combined with MS Word comments) - and traditional feedback (face-to-face meetings combined with MS Word comments) affect the improvement of academic writing, critical thinking and achievement motivation among university students and researchers. The study design was reviewed and approved by the Ethics Review Committee on Human Research at Tokyo University of Agriculture and Technology, Japan (No.191206-3151).

\subsection{Participants}

There were 19 initial participants, but three of them withdrew later, leaving 16 active participants: 7 Vietnamese, 3 Bengalis, 2 Egyptians, 2 Japanese, 1 Iraqi, and 1 Irani (Table 1). All participants had completed undergraduate degrees and were at a graduate institute. One participant was enrolled at South Valley University in Egypt, and all others at Tokyo University of Agriculture and Technology in Japan. The participation was voluntary: all the participants signed an informed consent. The participants were divided into three groups: Group 1 (Experimental 1), Group 2 (Experimental 2), and Group 3 (Control). There was no significant age difference between the groups $\left(\chi^{2}=1.57, d f=2\right.$, Sig. $=0.46$ ). To avoid bias in dividing participants into the three research groups and for enhancing balance among these groups the authors assigned participants based on their research experience which was reflected by the participants' current position, participants were divided also based on their English proficiency which can be understood from their grade on an international English certificate such as TOEFL and IELTS, their scientific experiences in academic writing is also important; therefore each participant was assigned to a research group based on his/her international publications that were written in English, and each group had only one female at most. Moreover, participants' grades in the pretest were a critical criterion for dividing participants into research groups.

\subsection{Methodology}

The participants were given the task of writing an academic paper: it could be for a journal article or a conference paper or just an internal report meant for their lab or professor using a scientific publication format with a suggested length of 2 to 10 pages. A reviewer, who is a domain expert with more than 13 years of experience as a researcher/reviewer, was assigned to each participant and worked with the participant in a one-on-one fashion using one of the interaction modes. There were four reviewers, and each reviewer worked with at least two participants each in a different group. Each participant received feedback on their writing using the mode of interaction (synchronous, asynchronous or face-to-face) according to their group. Each participant had five interaction sessions with the reviewer within a four-week period. The entire study was conducted from 14 December, 2019 through 7 March, 2020. 
Table 1

Participants' information

\begin{tabular}{|c|c|c|c|c|c|}
\hline The Research Groups & Average age & Current position & English Certificate & International Publications & Gender \\
\hline Group 1: & 29 & $1 \mathrm{Ph} . \mathrm{D}$ holder & 5 have & 5 have & 0 female \\
\hline 6 asynchronous e-feedback & & 5 Ph.D students & $\begin{array}{l}1 \text { has no } \\
\text { international } \\
\text { English certificate }\end{array}$ & $\begin{array}{l}1 \text { has no international } \\
\text { publication }\end{array}$ & 6 males \\
\hline Group 2: & 30 & 1 Ph.D holder & 4 have & 3 have & 1 female \\
\hline 5 synchronous e-feedback & & $\begin{array}{l}3 \text { Ph.D students } \\
1 \mathrm{MSc} \text { student }\end{array}$ & $\begin{array}{l}1 \text { has no } \\
\text { international } \\
\text { English certificate }\end{array}$ & $\begin{array}{l}2 \text { have no international } \\
\text { publication }\end{array}$ & 4 males \\
\hline Group 3: & 27 & 1 Ph.D holder & 4 have & 4 have & 1 female \\
\hline 5 face-to-face feedback & & $\begin{array}{l}3 \text { Ph.D students } \\
1 \text { MSc student }\end{array}$ & $\begin{array}{l}1 \text { has no } \\
\text { international } \\
\text { English certificate }\end{array}$ & $\begin{array}{l}1 \text { has no international } \\
\text { publication }\end{array}$ & 4 males \\
\hline
\end{tabular}

The participants discussed the received comments on their writing, using Google Docs or MS Word, individually with the reviewer by one of the following methods: (1) Asynchronous e-feedback text: the reviewer used email for discussing the feedback in delayed interaction with the participant (Experimental Group 1). (2) Synchronous efeedback audio: the reviewer used Skype for discussing the feedback in real-time interaction with the participant (Experimental Group 2). (3) Face-to-face meeting: the reviewer discussed the feedback in face-to-face interaction with the participant (Control group 1).

\subsection{Measurement tools (objective \& subjective)}

\subsubsection{Academic writing assessment rubrics}

The reviewers rated the quality of academic writing at each stage using the Academic Writing Assessment Rubrics that was designed based on prior studies (Moriarty, 1997; Newman et al., 1997; Swales \& Feak, 2004, 2012; Derish et al., 2007; Bauer et al., 2009; Glasman-Deal, 2010; Biber et al., 2011; Bailey, 2014; Ecarnot et al., 2015; Razi, 2015; Wallwork, 2016). It consisted of three main criteria: Mechanics of academic writing, Content Structure and Language of academic writing with a total of 16 indicators. Each indicator was graded on a scale of 0-10, with 0-2 meaning inadequate ability and 8-10 meaning excellent ability. We revised this rubric slightly based on the advice of three professors at our university.

\subsubsection{Achievement motives scale}

We used Achievement Motives Scale (Hermans, 1970; Lang \& Fries, 2006) which is applicable for university students and researchers because its reliability coefficient using the Cronbach Alpha Test was measured to be 0.79 (Demirel \& Arslan Turan, 2010). It consists of 12 items, each being answerable on a five-point scale from strongly disagree 
(1) to strongly agree (5); except for two negative questions (4 and 5), the scales are inverted.

\subsubsection{Critical thinking questionnaire}

We asked the participants to answer the Critical Thinking Questionnaire, based on the Watson-Glaser Critical Thinking Appraisal, which has a reasonably high level of statistical reliability (Behrens, 1996; Bernard et al., 2008). It has four main criteria: recognition of assumption, interpretation, deduction, induction, and evaluation of arguments. It consists of 22 items, each being answerable on a five-point scale from strongly disagree (1) to strongly agree (5).

\subsubsection{Semi-structured interview}

We also conducted a semi-structured interview to get in-depth subjective feedback on the pros and cons of each interaction method. The interview consisted of 22 questions, half of which were closed questions, with the possible answers being Yes (2), I don't know (1), or No (0); these questions were based on the Acceptance Technology Model (ATM) (Scherer et al., 2019). The remaining questions were free-response type.

The interviews were conducted orally: the participants' responses were recorded using a microphone and later transcribed. We used a Laptops Lenovo ThinkPad, free voice recorder software on Win 10, and a ZealSound portable microphone.

\subsection{Procedure}

The experiment was conducted over three months, but for each participant it ran for about four weeks. Each participant had three interaction sessions, one each week, to receive feedback on their writing. The mode of interaction - synchronous, asynchronous, or faceto-face - depended on the group to which the participant was assigned. A flowchart of the experiment is shown in Fig. 1, and the tasks for each week are described below.

First week: The participants were called for a 30-minute meeting to explain the experiment, in which they were given a brief presentation about the experiment and were asked to read and sign the informed consent. They also filled out a background questionnaire, the achievement motives scale, and a critical thinking questionnaire. Then they were asked to prepare the first version of their academic writing (2-10 pages) within one week. They could base this paper on their previous or ongoing research, which needed to be written in English. A reviewer was assigned to each participant, as explained in Sec. 3.2, who applied the academic writing assessment rubrics to rate the submitted writing sample. Each participant was assigned to one of the three interaction groups - synchronous, asynchronous, or face-to-face (control) - based on their background and their score on the academic writing assessment rubrics. The participant's responses to both the questionnaires and their score of the academic writing assessment rubrics was combined into the pretest score.

Second week: The reviewer sent an email with an attached Google Docs or MS Word file that included the reviewers' comments on the participants' academic writing. Two days after sending the comments, the interaction between the participant and the reviewer proceeded according to the participant's group as follows: Group 1 (Synchronous): A 15-minute Skype meeting between the participant and the reviewer to discuss the comments on the submitted writing. Group 2 (Asynchronous): The participant 
asked questions to discuss comments on the writing by sending an email to the reviewer, who responded within two days. Group 3 (Face-to-face): A 15-minute face-to-face meeting between the participants and the reviewer to discuss the comments on the submitted writing. After receiving the comments, the participant was asked to revise her or his academic writings, and submit the next version within two days.

Third week: The same procedure as the 2 nd week was repeated.

Fourth week: First, the same procedure as the 2 nd week was repeated, after which the participant produced the 4th version of their academic writing. This was rated by the reviewer through applying the writing assessment rubrics as before. Then the participant gave their feedback on the mode of interaction through a semi-structured interview, and filled out again the questionnaires for both the achievement-motives and critical thinking scales. The responses of these two questionnaires were combined with the academic writing assessment rubrics grade for the 4th version of academic writing into the posttest score.

\section{Results and discussion}

\subsection{Pretest: Academic writing, achievement motivation, critical thinking skills}

As the number of participants in each group was less than seven, we applied the KruskalWallis nonparametric statistical test (Table 2) to confirm that there was no significant difference among the three groups in the academic writing assessment rubrics, achievement motivation, or critical thinking skills scales. The distribution of participants in the three groups was considered to be balanced.

Table 2

Average differences between three groups

\begin{tabular}{lccccccc}
\hline \multirow{2}{*}{ Groups } & \multicolumn{4}{c}{ Achievement } & \multicolumn{2}{c}{ Critical Thinking } & \multicolumn{2}{c}{ Academic Writing } \\
& $\mathrm{N}$ & \multicolumn{2}{c}{ Motives Scale } & \multicolumn{2}{c}{ Questionnaire } & \multicolumn{2}{c}{ Assessment Rubrics } \\
& & $\mathrm{M}$ & $\mathrm{SD}$ & $\mathrm{M}$ & $\mathrm{SD}$ & $\mathrm{M}$ & $\mathrm{SD}$ \\
\hline Asynchronous e-feedback & 6 & 8.33 & 0.35 & 7.83 & 0.47 & 9.00 & 0.84 \\
Synchronous e-feedback & 5 & 6.60 & 0.41 & 9.00 & 0.91 & 9.80 & 1.06 \\
Face-to-face feedback & 5 & 10.60 & 0.52 & 8.80 & 0.66 & 6.60 & 0.92 \\
Kruskal-Wallis test & & $\chi^{2}=1.83, p=0.4$ & $\chi^{2}=0.19, p=0.91$ & $\chi^{2}=1.24, p=0.54$ \\
\hline
\end{tabular}

A semi-structured interview was conducted with each participant immediately after submitting the fourth version of their academic writing. The interview questions were based on the technology acceptance model (TAM). The participants' consent was obtained to record the interview. Each interview took an average of 16 minutes, which was audio recorded and transcribed for analysis. We recorded 192 minutes of interviews and collected more than 432 comments. Excerpted parts of these comments are grouped together to reflect advantages and disadvantages of various interaction modes. 


\section{TAT畩大楼粠 \\ 東京農工大学}

Tokyo University of Agriculture and Technology

\section{Let's Improve our English Academic Writing}

- Answer two questionnaires (takes 15 minutes).

- Report in 2-5 pages your academic progress in an academic paper format (within one week takes around 60 minutes).
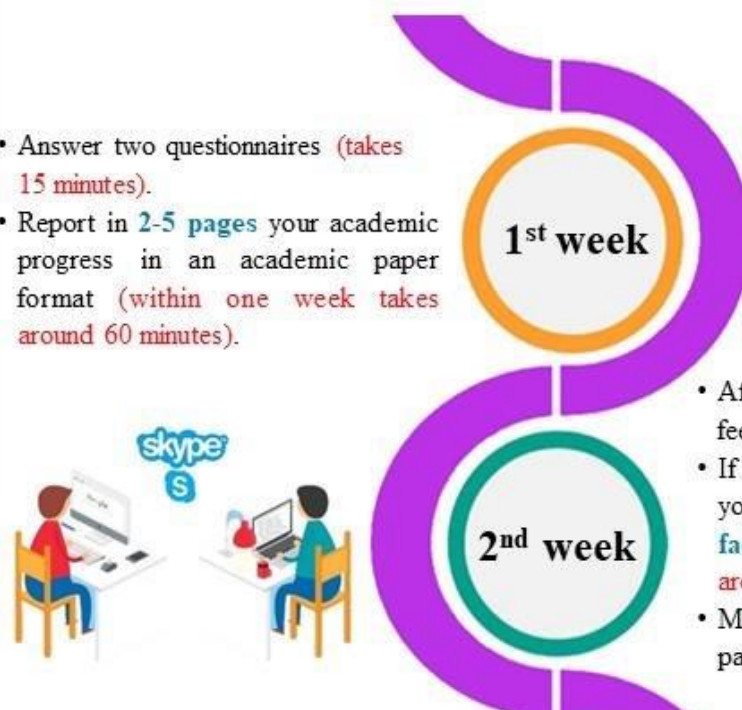

- After two days you will receive feedback.

- If you need to discuss the feedback you will be invited for a Skype or face to face meeting (will take around 15 minutes)

- Modify and send new version of your paper

- After two days you will receive feedback.

- If you need to discuss the feedback you will be invited for a Skype or face to face meeting (takes around 15 minutes).

- Modify and send new version of your paper.
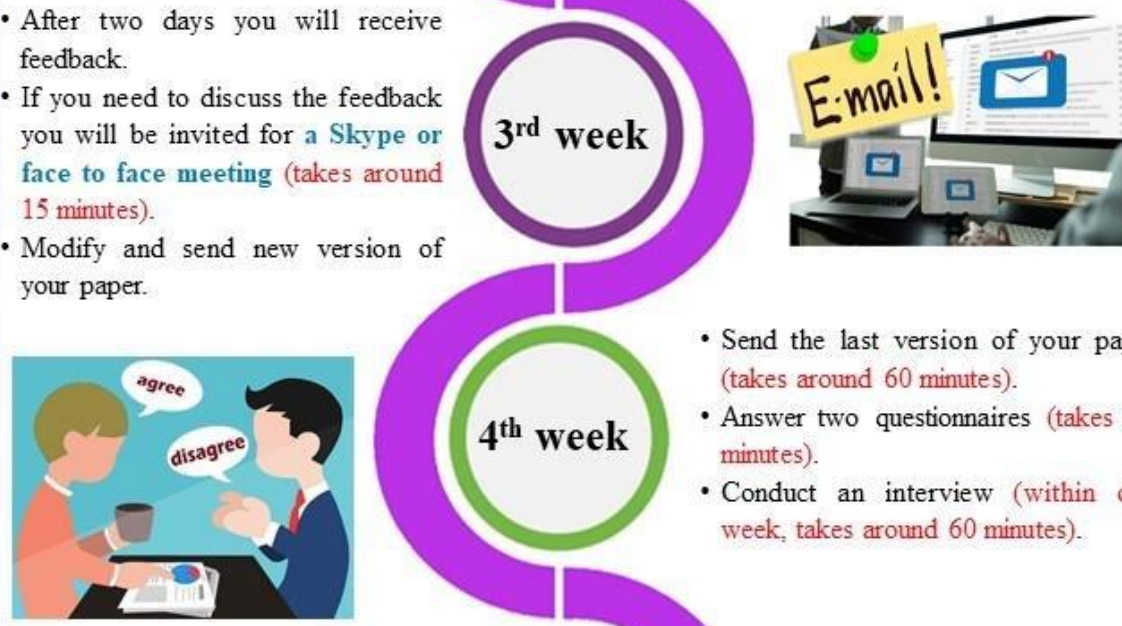

- Send the last version of your paper (takes around 60 minutes).

Answer two questionnaires (takes 15 minutes).

- Conduct an interview (within one week, takes around 60 minutes).

For more information: mmh2019@m2.tuat.ac.jp

Fig. 1. Conceptual framework of the dual mapping learning environment 


\subsection{Academic writing skills - Quantitative and qualitative analysis}

In the first stage of the posttest interviews, the participants responded to closed questions on a 3-point Likert scale (Yes $=2$, I don't know $=1$, and No $=0$ ). No significant difference $\left(\chi^{2}=0.76, p=0.68\right)$ was found among the three groups, or in any of the TAM dimensions of perceived ease of use, perceived usefulness, attitude to use, and intention to use (Fig. 2).

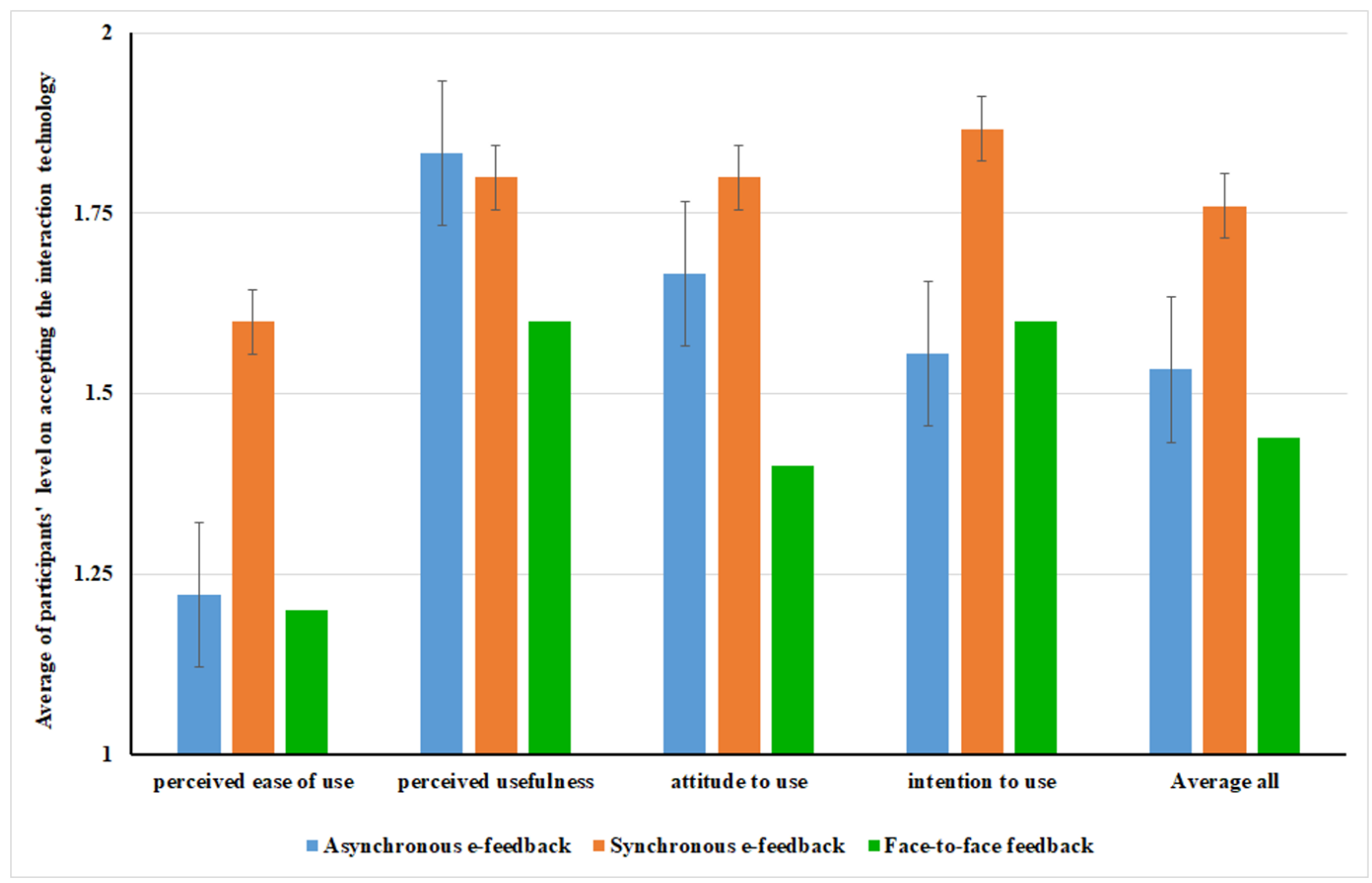

Fig. 2. Participants' responses correlated to the technology acceptance model (TAM)

In the second stage of the posttest interviews, the participants, having received feedback on four versions of academic writing, were asked to explain the reasons for their posttest answers. We wanted to know their suggestions for improvements, and to understand why certain aspects of the interactions were considered positive. However, the participants were asked to explain their answers without labelling them positive or negative. Their comments were classified as advantages and disadvantages in a later analysis. We present in Table 4 the key relevant concepts from the participants extracted from their posttest interviews. To maintain anonymity, participants' self-chosen IDs are used which follow concepts extracted from their comments.

We also quantitatively analyzed the improvement in academic writing skills by comparing pretests and posttests between versions 1 and 3 of the academic writings in all the experimental and control groups. The results of applying the Wilcoxon Signed Ranks Test are shown in Table 3 for the asynchronous group $(Z=3.20, P=0.03)$, the synchronous group $(Z=2.02, P=0.04)$, and the face-to-face group $(Z=2.02, P=0.04)$. 
Table 3

Wilcoxon signed ranks of academic writing assessment rubrics

\begin{tabular}{lccc}
\hline \multirow{2}{*}{ Groups } & \multirow{2}{*}{ Academic Writing Assessment Rubrics } \\
& & $\mathrm{Z}$ & $\mathrm{P}$ \\
\hline Asynchronous e-feedback & 6 & 3.20 & 0.03 \\
Synchronous e-feedback & 5 & 2.02 & 0.04 \\
Face-to-face feedback & 5 & 2.02 & 0.04 \\
\hline
\end{tabular}

Overall, both e-feedback and face-to-face feedback are found to improve academic writing.

To investigate whether there is a significant difference among the three modalities of interaction, we applied the Kruskal-Wallis test to the participants' academic writing assessment rubric. The results revealed a significant difference between the three groups $(\chi 2=8.74, p=0.01)$. The synchronous e-feedback group gained a significantly higher score than the other two groups (Fig. 3). To better understand this difference, we further analyzed the writing assessment rubric with respect to its three components: content structure, language of writing, and mechanics of writing. The results indicate that the synchronous e-feedback group gained a significantly higher score on the content structure $\left(\chi^{2}=6.99, p=0.03\right)$, and the language of academic writing $\left(\chi^{2}=8.08, p=0.02\right)$, compared to the other two groups. However, there is no significant difference in improving the mechanics of academic writing between the three groups $\left(\chi^{2}=3.20, p=\right.$ $0.20)$.

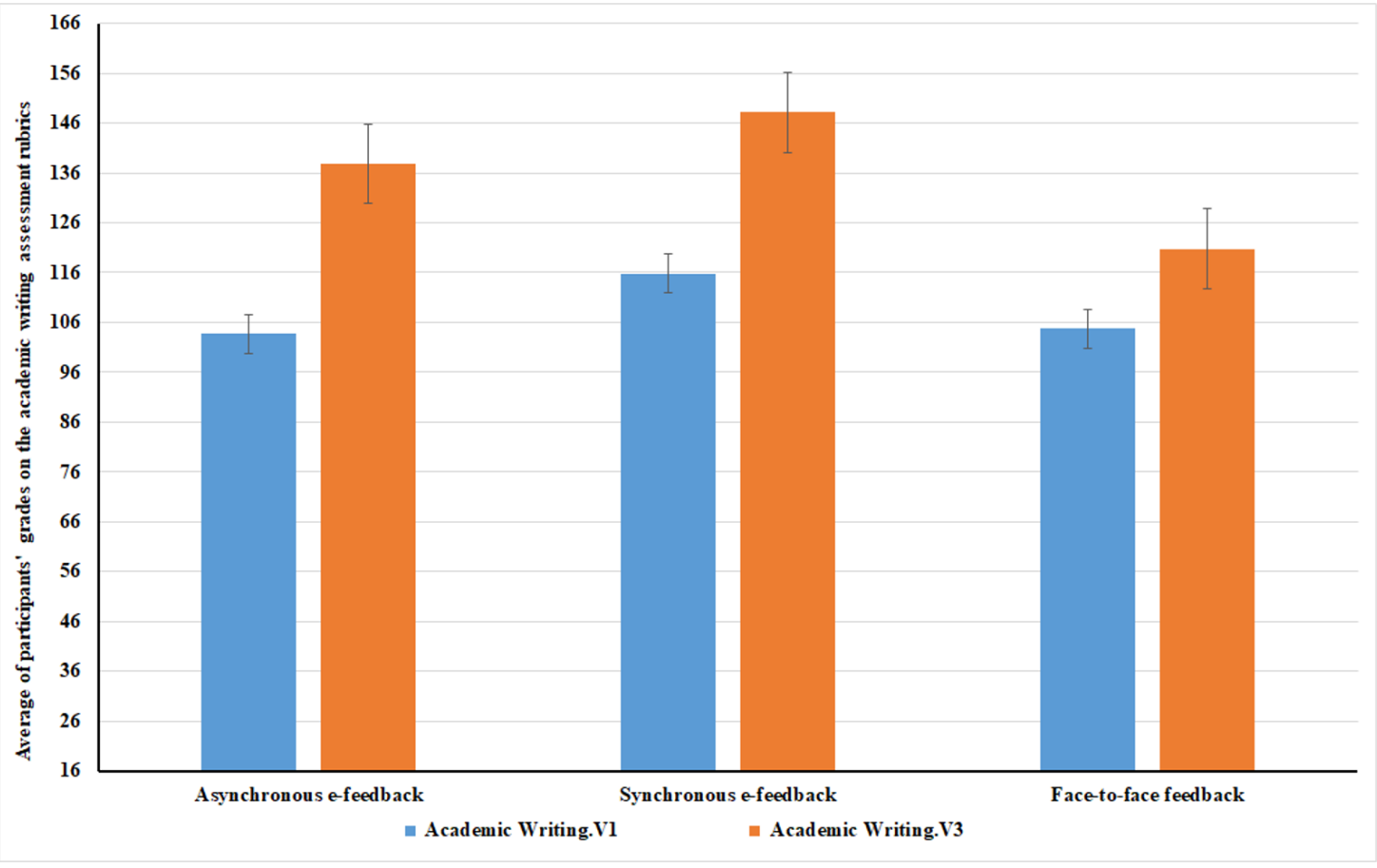

Fig. 3. Improving academic writing through various interaction groups 
Table 4

Participants' viewpoints in various interaction groups regarding the received feedback on their academic writings

\begin{tabular}{|c|c|c|c|c|c|c|}
\hline & \multicolumn{2}{|c|}{ Asynchronous e-feedback } & \multicolumn{2}{|c|}{ Synchronous e-feedback } & \multicolumn{2}{|c|}{ Face-to-face feedback } \\
\hline & Pros & Cons & Pros & Cons & Pros & Cons \\
\hline $\begin{array}{l}\text { Feedback on the } \\
\text { written language }\end{array}$ & $\begin{array}{l}\text { - prevents } \\
\text { misunderstanding } \\
\text { (N12, S11, \& } \\
\text { Q36). } \\
\text { - allows direct and } \\
\text { clear interactions } \\
\text { (N99). } \\
\text { - helps to improve } \\
\text { accuracy with } \\
\text { academic writing } \\
\text { because the } \\
\text { reviewer can easily } \\
\text { point out } \\
\text { corrections needed } \\
\text { with grammatical } \\
\text { errors (A55, F22, } \\
\& \text { K11). }\end{array}$ & $\begin{array}{l}\text { - After receiving } \\
\text { feedback by email, } \\
\text { some participants } \\
\text { always ask for a } \\
\text { face-to-face meeting } \\
\text { to clarify some } \\
\text { points (P00 \& A55). } \\
\text { - More details and } \\
\text { discussions are } \\
\text { needed to modify } \\
\text { writing mistakes } \\
\text { (P00 \& K11). }\end{array}$ & $\begin{array}{l}\text { - improves } \\
\text { accuracy (M19 \& } \\
\text { A00) by not } \\
\text { repeating the same } \\
\text { mistakes (M33). } \\
\text { - providing } \\
\text { feedback about } \\
\text { paraphrasing and } \\
\text { references (A00) } \\
\text { - enabling a better } \\
\text { understanding of } \\
\text { related academic } \\
\text { papers (M33) } \\
\text { - drawing effective } \\
\text { conclusions and } \\
\text { improving the } \\
\text { clarity of ideas } \\
\text { (A00). } \\
\text { - reducing } \\
\text { ambiguity (M19). }\end{array}$ & $\begin{array}{l}\text { - improperly } \\
\text { rephrasing oral } \\
\text { comments can } \\
\text { change the } \\
\text { meaning of the } \\
\text { reviewer } \\
\text { comments (M19). } \\
\text { - it is not as } \\
\text { accurate because } \\
\text { the comments are } \\
\text { not written (A94). }\end{array}$ & $\begin{array}{l}\text { - allows for asking } \\
\text { more details from } \\
\text { the reviewer (S31, } \\
\text { D13, \& S11) } \\
\text { - allows the } \\
\text { reviewer to explain } \\
\text { exactly the ideas } \\
\text { that are needed, } \\
\text { and helps the writer } \\
\text { to ask the reviewer } \\
\text { directly (S31 \& } \\
\text { D13). } \\
\text { - helps the reviewer } \\
\text { to explain how to } \\
\text { avoid repeating } \\
\text { mistakes, and } \\
\text { specifically point to } \\
\text { places that need } \\
\text { modifying (D13) } \\
\text { - increased } \\
\text { accuracy (S31 \& } \\
\text { S11), } \\
\text { - leads to more } \\
\text { appropriate words } \\
\text { and connectors in } \\
\text { the paper and } \\
\text { improving the flow } \\
\text { of written ideas } \\
\text { (S31 \& Q36). }\end{array}$ & $\begin{array}{l}\text { - Face-to-face } \\
\text { interaction } \\
\text { confuses me } \\
\text { because even if } \\
\text { the reviewer can } \\
\text { speak Japanese } \\
\text { same as me, } \\
\text { comments will be } \\
\text { explained in } \\
\text { English (S11). }\end{array}$ \\
\hline Feedback interaction & $\begin{array}{l}\text { - Email is more } \\
\text { understandable } \\
\text { (N11 \& A00) } \\
\text { - sending } \\
\text { documented } \\
\text { feedback (A55, } \\
\text { K11, \& A55). } \\
\text { - it can be read } \\
\text { again when needed } \\
\text { (A55, N99, \& } \\
\text { N12). } \\
\text { - simple (F22 \& } \\
\text { P00). } \\
\text { - allows tracking } \\
\text { of information } \\
\text { (A55 \& N12). } \\
\text { - causes less } \\
\text { confusion, }\end{array}$ & $\begin{array}{l}\text { - It can be difficult to } \\
\text { remember the } \\
\text { feedback due to the } \\
\text { volume of received } \\
\text { emails (K11). }\end{array}$ & $\begin{array}{l}\text { - It is convenient } \\
\text { in not having to } \\
\text { use transportation } \\
\text { (N11), } \\
\text { - flexible in terms } \\
\text { of time (A94 \& } \\
\text { M33) and place } \\
\text { (M19). } \\
\text { - provides short } \\
\text { and focused } \\
\text { feedback (A00) } \\
\text { - is effective and } \\
\text { immediate (N11). } \\
\text { - can be easily } \\
\text { used for } \\
\text { brainstorming, } \\
\text { providing more } \\
\text { detailed feedback }\end{array}$ & $\begin{array}{l}\text { - Sometimes } \\
\text { missing ideas } \\
(\mathrm{A} 00)\end{array}$ & $\begin{array}{l}\text { - Suitable for junior } \\
\text { researchers, which } \\
\text { is required in initial } \\
\text { stages of writing } \\
\text { (S11). } \\
\text { - The reviewer can } \\
\text { suggest some } \\
\text { related papers to } \\
\text { help in improving } \\
\text { the academic } \\
\text { writing (D13). } \\
\text { - can help to focus } \\
\text { on all points in the } \\
\text { paper better and } \\
\text { more easily than } \\
\text { email (S11), } \\
\text { - giving quick } \\
\text { feedback compared }\end{array}$ & $\begin{array}{l}\text { - difficult to } \\
\text { remember the } \\
\text { provided } \\
\text { feedback, to recall } \\
\text { when I need it } \\
\text { (S11 \& S18), } \\
\text { - is complicated } \\
\text { for me even when } \\
\text { I record the } \\
\text { reviewer's } \\
\text { comments (S11). } \\
\text { - Providing } \\
\text { feedback one time } \\
\text { does not help me } \\
\text { to concentrate } \\
\text { (S18). }\end{array}$ \\
\hline
\end{tabular}


especially when

both the writer and

reviewer are not

native speakers

(S11 \& Q36).

- allows figure

attachments (S11)

- It provides

adequate time

(A55 \& A00)

- and fast response

(S11 \& K11) to the

writers. One can

adapt the time

schedule (F22,

N99, \& K11) to

provide flexibility

(A55) and across

time zones (N99).

- provides for

understanding

when asking for

more details (F22)

- Email gives a

chance to discuss

more details which

are easier to

remember as

comments are

documented (M19

\& A94),

- helps to ask more

specific points as

to where and what

kind of help is

needed (M19).
(M33)

- feedback can be recorded (M33).

- can help students

in understanding

and remembering

the feedback (A94

\& N11),

- provides a good

alternative

platform for

discussion (M19). with email which can save time (S11 \& D13).

- writing scientific papers using face-

to-face is the

easiest way to

clarify written

feedback because

on Skype

sometimes ideas

are missed that are

presented in the

discussion (A00).

- easy to use paper, pens, figures and

various other tools during face-to-face interaction (M19)

Emotional aspects

\author{
- When writing a \\ long scientific \\ manuscript Skype or \\ face-to-face \\ interaction is \\ preferable (N99 \& \\ $\mathrm{K} 11)$
}

- sharing not only
information about
the writing, but
also the attitude
and the emotions
accompanying the
feedback, allowing
for a better
understanding
(Q36)

In the first research question, we try to investigate how various modes of interaction (asynchronous e-feedback vs. synchronous e-feedback vs. face-to-face feedback), affect the improvement of academic writing skills for university students and 
researchers. In order to answer the mentioned question, we analyzed Academic Writing Assessment Rubrics that were used for measuring the 4 versions of academic writing manuscripts that were submitted by participants. For understanding the acceptance level of using the technology for providing asynchronous or synchronous e-feedback. We also analyzed the data of the questionnaire that is designed based on the TAM model. The result refers to no significant difference being found among the three groups in accepting the applied technology for providing feedback in terms of ease of use, perceived usefulness, attitude to use, and intention to use.

The results indicate that providing e-feedback through the Skype application synchronous group - has a significantly higher score than the other two groups. The results can be supported by prior research results that indicate synchronous interaction can provide direct instruction (Murphy et al., 2011) and decreases ambiguity with learning experiences because it provides immediate e-feedback (Basaran \& Yalman, 2020; Cha \& Park, 2010; Hrastinski, 2008). Consequently, when the professor would like to contact their students for providing feedback on their writing, it is recommended that they use synchronous interaction especially in online interaction. Software developers who seek to develop a collaborative writing system should add more features for improving the quality of synchronous interaction.

\subsection{Achievement motivation - Quantitative and qualitative analysis}

The results of analyzing the achievement motivation questionnaire indicate that the synchronous e-feedback group gained a significantly higher score on achievement motivation than the other two groups: Kruskal-Wallis test result is $\left(\chi^{2}=8.63, p=0.01\right)$. For comparing the improvement in achievement motivation across the three groups, we analyzed the pretest and posttest data. The Wilcoxon Signed Ranks test results for the asynchronous group are $(Z=0.54, P=0.59)$, for the synchronous group they are $(Z=$ $1.75, P=0.08)$, and for the face-to-face feedback group they are $(Z=1.62, P=0.10)$ as shown in Table 5. Though there is no significant difference among the three groups, the level of improvement among participants in the synchronous e-feedback group is slightly higher than the other groups (Fig. 4).

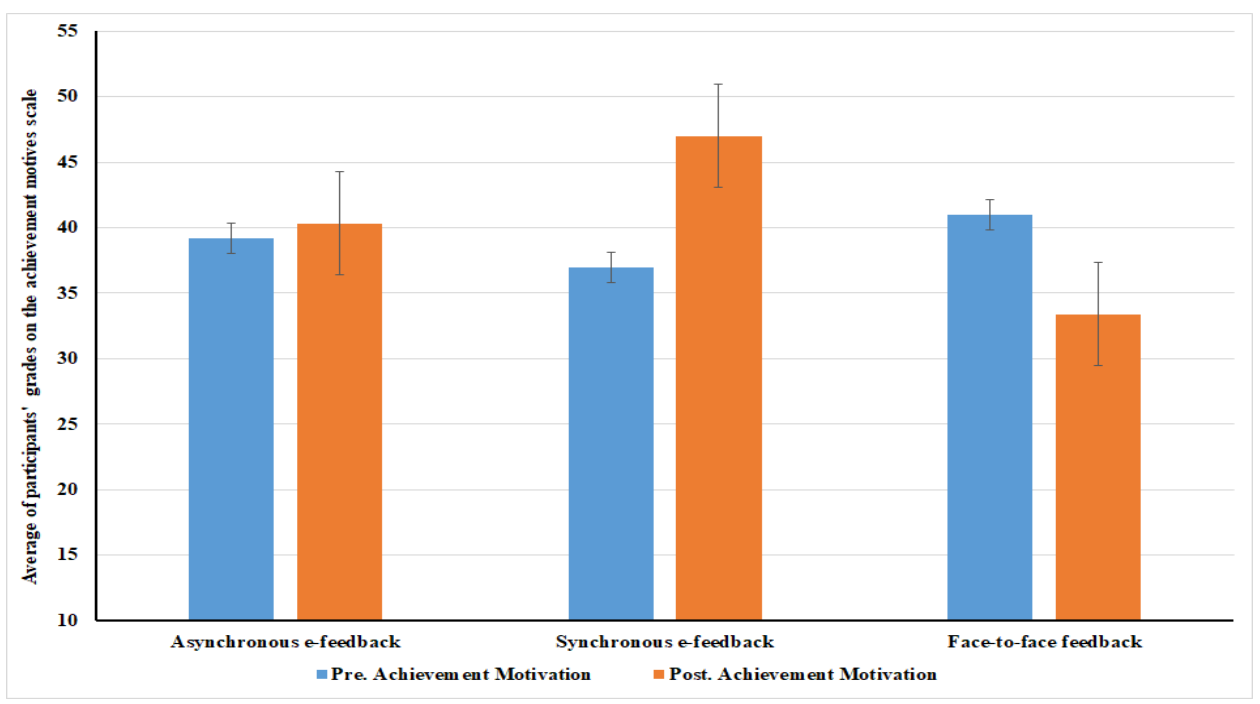

Fig. 4. Improving achievement motivation 
Table 5

Wilcoxon signed ranks of achievement motivation scale

\begin{tabular}{lccc}
\hline \multirow{2}{*}{ Groups } & \multirow{2}{*}{ N } & \multicolumn{2}{c}{ Achievement Motives Scale } \\
& & $\mathrm{Z}$ & $\mathrm{P}$ \\
\hline Asynchronous e-feedback & 6 & 0.54 & 0.59 \\
Synchronous e-feedback & 5 & 1.75 & 0.08 \\
Face-to-face feedback & 5 & 1.62 & 0.10 \\
\hline
\end{tabular}

Table 6

Participants' viewpoints in various interaction groups regarding improving their achievement motivation

\begin{tabular}{|c|c|c|c|c|c|c|}
\hline & \multicolumn{2}{|c|}{ Asynchronous e-feedback } & \multicolumn{2}{|c|}{ Synchronous e-feedback } & \multicolumn{2}{|c|}{ Face-to-face feedback } \\
\hline & Pros & Cons & Pros & Cons & Pros & Cons \\
\hline $\begin{array}{l}\text { Feedback on the } \\
\text { written language }\end{array}$ & & $\begin{array}{l}\text { - Email provides } \\
\text { complicated } \\
\text { comments and } \\
\text { some sentences I } \\
\text { cannot understand } \\
\text { in the proper way } \\
\text { (N12). }\end{array}$ & $\begin{array}{l}\text { - helps me to } \\
\text { achieve my } \\
\text { writing goals } \\
\text { (A00, N11, } \\
\text { A94). }\end{array}$ & $\begin{array}{l}\text { - I believe that } \\
\text { face-to-face } \\
\text { provides me with } \\
\text { more details } \\
\text { (N11). }\end{array}$ & $\begin{array}{l}\text { - helpful for me } \\
\text { to accomplish } \\
\text { my writing (D13, } \\
\text { S31) } \\
\text { - provides for } \\
\text { receiving } \\
\text { valuable } \\
\text { comments for } \\
\text { improving my } \\
\text { writing (D13) }\end{array}$ & $\begin{array}{l}\text { - For non-native } \\
\text { English speaker, } \\
\text { using email is } \\
\text { better than oral } \\
\text { interaction (S18, } \\
\text { S11). }\end{array}$ \\
\hline $\begin{array}{l}\text { Feedback } \\
\text { interaction }\end{array}$ & $\begin{array}{r}\text { - easy to } \\
\text { understand } \\
(\mathrm{F} 22, \text { A55). } \\
\text { - a collaborative } \\
\text { activity (K11, } \\
\text { A55). } \\
\text { - saves time } \\
\text { (P00, F22, N99). }\end{array}$ & $\begin{array}{r}\text { - Email cannot } \\
\text { provide } \\
\text { immediate } \\
\text { feedback (K11, } \\
\text { P00, A55). } \\
\text { - immediate } \\
\text { interaction is } \\
\text { better for } \\
\text { academic writing } \\
\text { [either using } \\
\text { Skype or face-to- } \\
\text { face] (A55, K11). }\end{array}$ & $\begin{array}{r}\text { - is an easy } \\
\text { method and } \\
\text { easier than } \\
\text { face-to-face } \\
\text { (A00, M19, } \\
\text { N11, A94) } \\
\text { - It is much } \\
\text { more flexible } \\
\text { than face-to- } \\
\text { face (N11). } \\
\text { - receiving } \\
\text { immediate } \\
\text { feedback } \\
\text { (N11). }\end{array}$ & & $\begin{array}{r}\text { - more } \\
\text { convenient (D13, } \\
\text { S18) } \\
\text { - providing more } \\
\text { freedom to } \\
\text { discuss writing } \\
\text { with the } \\
\text { reviewer (S31) }\end{array}$ & $\begin{array}{r}\text { - Receiving } \\
\text { feedback face-to- } \\
\text { face is harder } \\
\text { than email } \\
\text { because the } \\
\text { reviewer in the } \\
\text { email can specify } \\
\text { the problem and } \\
\text { explain how to } \\
\text { correct it }(\mathrm{Q} 36, \\
\mathrm{S} 11) .\end{array}$ \\
\hline $\begin{array}{l}\text { Emotional } \\
\text { aspects }\end{array}$ & $\begin{array}{r}\text { - satisfying } \\
\text { (K11) } \\
\text { - interesting I } \\
\text { would like to use } \\
\text { it in the future } \\
\text { (F22). } \\
\text { - do not feel any } \\
\text { psychological } \\
\text { burden (K11, }\end{array}$ & $\begin{array}{r}\text { - Email is not } \\
\text { interesting (K11, } \\
\text { P00, A55). } \\
\text { - I have a little bit } \\
\text { of a psychological } \\
\text { problem through } \\
\text { email (F22). }\end{array}$ & $\begin{array}{r}\text { - I do not prefer } \\
\text { receiving } \\
\text { feedback } \\
\text { through it } \\
(\mathrm{A} 00, \mathrm{M} 19, \\
\mathrm{N} 11, \mathrm{~A} 94) . \\
\text { - It doesn't } \\
\text { make writers } \\
\text { nervous and it }\end{array}$ & $\begin{array}{r}\text { - It leads to a } \\
\text { psychological } \\
\text { burden } \\
(\mathrm{A} 00) . \\
\text { - It is difficult to } \\
\text { focus on my work } \\
\text { and avoid } \\
\text { discussing other } \\
\text { issues not related }\end{array}$ & $\begin{array}{r}\text { - can receive } \\
\text { facial } \\
\text { expressions from } \\
\text { my reviewer } \\
\text { which is } \\
\text { interesting (D13) } \\
\text { - helpful for } \\
\text { establishing a } \\
\text { good }\end{array}$ & $\begin{array}{r}\text { - Face-to-face for } \\
\text { one time is not } \\
\text { satisfactory } \\
(\mathrm{S} 11) \text {. } \\
\text { - It has a } \\
\text { psychological } \\
\text { burden toward } \\
\text { using it in } \\
\text { academic writing }\end{array}$ \\
\hline
\end{tabular}


A55).

Feedback

Challenges

supports
sharing
emotion $(\mathrm{N} 11)$.
- It hasn't any
psychological
burden (A94).
- It is important
for writing

to my academic

writing (M19).

-It is not

interesting (A94).

relationship,

along with being

satisfying and

enjoyable (S31)

(A94).

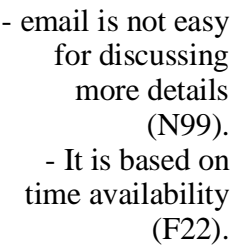

(F22).

$$
\begin{array}{r}
\text { - Skype is not } \\
\text { uncomfortable to } \\
\text { use, yet, one has to } \\
\text { adapt to the } \\
\text { condition of the } \\
\text { internet and PC } \\
\text { audio quality }
\end{array}
$$

(D13).

- I recommend other researchers to use email not face-to-face (S11).

In relation to RQ2 (how various modes of interaction affect the improvement of the achievement motivation of the university students and researchers), the results have clearly shown there is no significant difference among the three groups in terms of improving achievement motivation. At the same time, as shown in Fig. 4, compared with using email or face-to-face meetings for providing feedback, using synchronous efeedback through Skype can support the participants to achieve better improvement in their achievement motivation. Because sometimes delayed written feedback decreased students' motivation as a result of making the student a passive recipient for the feedback, in contrast with immediate feedback (Hyland, 2011; Schillings et al., 2021); this is consistent with the participants' viewpoints (Table 6) which indicate that Email provides complicated feedback which is not easy for discussing details (N12 \& N99). Moreover, using Skype as a synchronous interaction technique can improve the students' motivation because it helps students to engage in effective discussions, which provides opportunities to practice brainstorming, thereby leading to improved engagement in learning skills which can lead to improve the achievement motivation (Heift \& Caws, 2000). Participants' viewpoints also support that when they mentioned receiving e-feedback through Skype application is easy (A00, M19, N11, A94) and much more flexible (N11).

From Fig. 4 it is clear that the achievement motivation decreased for the participants who used face to face interaction. The achievement motivation can be affected negatively by a number of factors like the conflict of styles between the reviewer and the writer (Zeynali, Pishghadam, \& Fatemi, 2019): our participants declared that face-to-face interaction for getting the feedback is harder than email and Skype meetings. Also, in almost all the sessions of providing feedback, the reviewers provided conflicting ideas. Although providing feedback through face-to-face interaction may lead to better management of the learning workload because of the immediate and detailed feedback that learners can get, it curtails the freedom of the participant, which may negatively affect the participants' motivation. This is consistent with Bouwmeester et al. (2019), who found that the student's motivation can be enhanced in the flipped classroom because they can practice learning autonomy, which is supported by the freedom in studying according to the students' own time and pace.

As a result, participants became demotivated while using face-to-face interaction. In addition, enhancing participants' motivation is required to avoid negative emotion 
while providing the feedback and achieving this is difficult, which leads to demotivating students (Filgona et al., 2020). Moreover, providing feedback on academic writing should balance between the writers' needs and the interaction modes to keep a suitable level of motivation that can support students' learning. Developing academic writing systems should provide learners and professors with various tools that make students more active through practicing brainstorming and presenting their viewpoints in the received efeedback. Therefore, it can support improving learners' achievement motivation.

\subsection{Critical thinking - Quantitative and qualitative analysis}

The quantitative data of applying a Kruskal-Wallis test showed that there is no significant difference between the synchronous e-feedback group, the asynchronous e-feedback group, and the face-to-face feedback group with respect to critical thinking $\left(\chi^{2}=0.79, p\right.$ $=0.67)$. The pretests and posttests were analyzed to assess the participants' critical thinking skills across the experimental and control groups. As shown in Table 7 and Fig. 5 , the results of the Wilcoxon Signed Ranks test for the asynchronous group are $(Z=0.40$, $P=0.69)$, for the synchronous e-feedback group they are $(Z=0.41, P=0.68)$, and for the face-to-face group results are $(Z=0.94, P=0.35)$.

Table 7

Wilcoxon signed ranks of critical thinking questionnaire

\begin{tabular}{lccc}
\hline \multirow{2}{*}{ Groups } & N & \multicolumn{2}{c}{ Critical Thinking Questionnaire } \\
& & $\mathrm{Z}$ & $\mathrm{P}$ \\
\hline Asynchronous e-feedback & 6 & 0.40 & 0.69 \\
Synchronous e-feedback & 5 & 0.41 & 0.68 \\
Face-to-face feedback & 5 & 0.94 & 0.35 \\
\hline
\end{tabular}

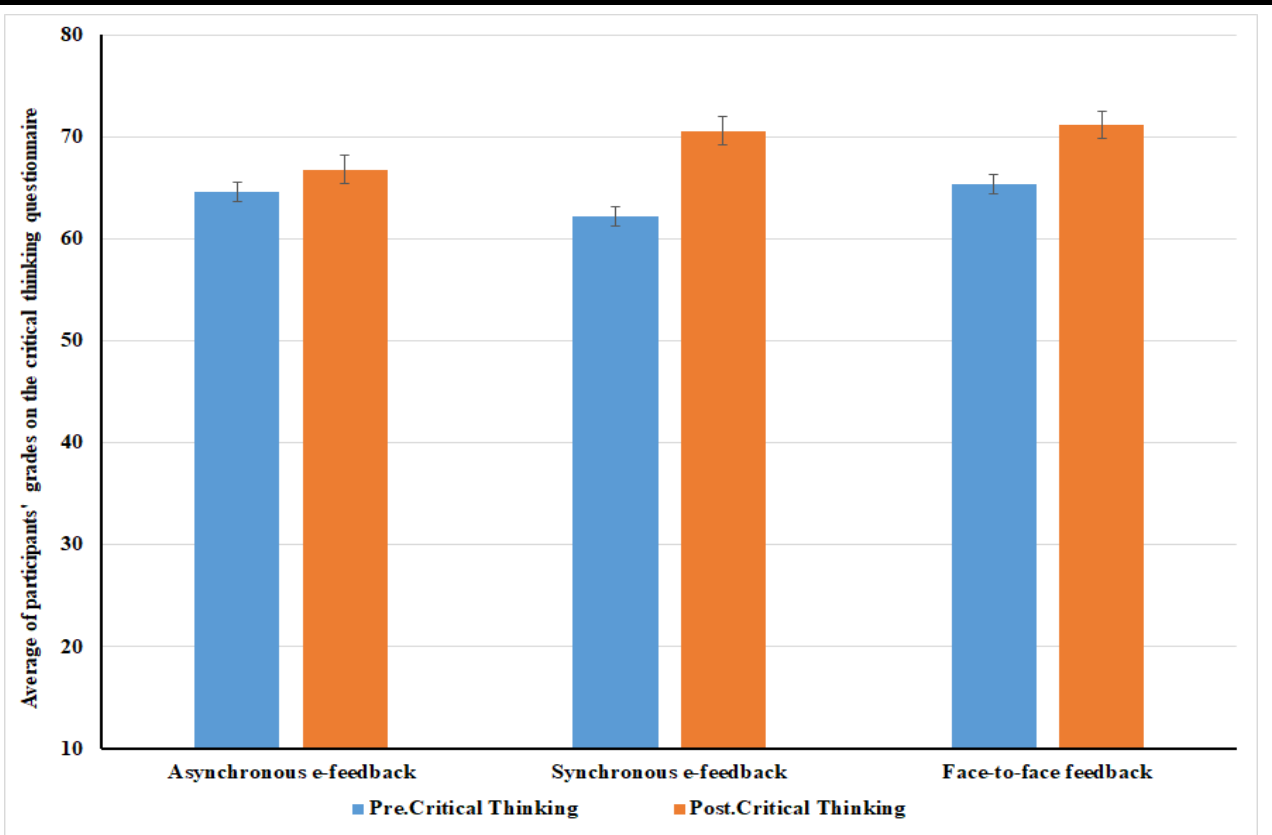

Fig. 5. Changes regarding participants' critical thinking 
Prior studies (Hall, 2017) have indicated a correlation between improving critical thinking and practicing academic writing. However, comments from our participants (Table 8 ) in the posttest interview are not so clear in this regard as shown below (Fig. 5).

Table 8

Participants' viewpoints in various interaction groups regarding improving their critical thinking skills

\begin{tabular}{|c|c|c|c|c|c|c|}
\hline & \multicolumn{2}{|c|}{ Asynchronous e-feedback } & \multicolumn{2}{|c|}{ Synchronous e-feedback } & \multicolumn{2}{|c|}{ Face-to-face feedback } \\
\hline & Pros & Cons & Pros & Cons & Pros & Cons \\
\hline $\begin{array}{l}\text { Feedback on the } \\
\text { written language }\end{array}$ & & $\begin{array}{r}\text { - Email is } \\
\text { difficult to } \\
\text { interpret } \\
\text { reviewer } \\
\text { feedback }(\mathrm{P} 00) . \\
\text { - Sometimes } \\
\text { email could not } \\
\text { help to present } \\
\text { ideas concretely } \\
\text { to the reviewers } \\
(\mathrm{P} 00) .\end{array}$ & $\begin{array}{r}\text { - It can easily } \\
\text { improve the logic } \\
\text { of presenting } \\
\text { academic } \\
\text { writing, because } \\
\text { a synchronous e- } \\
\text { discussion is } \\
\text { short and precise } \\
\text { (A94, A00). } \\
\text { - Reasons behind } \\
\text { corrections of } \\
\text { writing mistakes } \\
\text { could be } \\
\text { discussed (M33). }\end{array}$ & $\begin{array}{r}\text { - It easier to } \\
\text { use email to } \\
\text { ask for more } \\
\text { details in } \\
\text { specific points } \\
\text { and specify } \\
\text { where and } \\
\text { what kind of } \\
\text { help is needed } \\
\text { (M19, A94). }\end{array}$ & $\begin{array}{r}\text { - It is very } \\
\text { useful for } \\
\text { introduction } \\
\text { and discussion } \\
\text { sections that } \\
\text { require } \\
\text { argumentative } \\
\text { writing (S31). } \\
\text { - It can be used } \\
\text { to defend ideas } \\
(\mathrm{Q} 36) \\
\text { - understand } \\
\text { clarification of } \\
\text { ideas from a } \\
\text { reviewer (S31, } \\
\text { Q36). }\end{array}$ & \\
\hline $\begin{array}{l}\text { Feedback } \\
\text { interaction }\end{array}$ & $\begin{array}{l}\text { - In email, as } \\
\text { compared to } \\
\text { Skype, edited } \\
\text { points can be } \\
\text { seen and } \\
\text { modified easily } \\
\text { (A94). } \\
\text { - Email is better } \\
\text { for elaborating on } \\
\text { some points } \\
\text { (A55). }\end{array}$ & & & & & \\
\hline $\begin{array}{l}\text { Emotional } \\
\text { aspects }\end{array}$ & & & $\begin{array}{l}\text { - rather than } \\
\text { email this } \\
\text { interaction style } \\
\text { is preferable } \\
\text { when more } \\
\text { discussion is } \\
\text { needed (N99, } \\
\text { K11). } \\
\text { - It is interesting } \\
\text { and does not } \\
\text { cause boredom } \\
\text { (A94, A00). }\end{array}$ & & $\begin{array}{l}\text { - rather than } \\
\text { email this } \\
\text { interaction } \\
\text { style is } \\
\text { preferable } \\
\text { when more } \\
\text { discussion is } \\
\text { needed (N99, } \\
\text { K11). }\end{array}$ & $\begin{array}{l}\text {-Experience a } \\
\text { psychological } \\
\text { burden (Q36, } \\
\text { D11, M19, } \\
\text { A00). }\end{array}$ \\
\hline
\end{tabular}


Feedback

Challenges

Overall, in relation to RQ3, as shown in Fig. 5., various modes of interaction for providing e-feedback or conventional feedback can slightly improve the participants' critical thinking skills. Although there is no significant difference between the three groups with respect to improving critical thinking skills, the results of the current research can highlight the importance of using effective interaction modes for providing feedback on academic writings. The duration of conducting the experiment needs to be extended for getting better results. In addition, it was recommended for improving critical thinking to ask participants to focus on writing the most critical sections in the academic manuscripts such as the introduction and the discussion section that can easily reflect the improvement of critical thinking skills for the participants.

\section{Conclusion and implications}

For improving academic writing skills, critical thinking and achievement motivation, we compared the efficacy of two different interaction modes - synchronous e-feedback (in real-time, as with Skype) and asynchronous (based on emails) - and contrasted them with each other and with face-to-face interaction. The results reveal advantages and disadvantages of each interaction mode.

- Although feedback can enhance the improvement of university students and researchers' academic writing skills, synchronous e-feedback compared with other feedback modes supports writers to gain significantly higher scores on academic writing assessment rubrics.

- Achievement motivation can be improved by providing synchronous e-feedback and was found to be better than asynchronous e-feedback or face-to-face feedback. This can lead to a decrease in the dropout rate of learners from collaborative writing applications.

- There is no significant difference between the three interaction modes for critical thinking, and with respect to the technology acceptance model.

The following additional observations were made:

- Novice researchers, in contrast with senior researchers, prefer synchronous interactions, with or without technology, because it supports finding an immediate response to their questions, decreases learning time, and provides more details as needed.

- We need to embed synchronous interaction tools with collaborative writing systems by incorporating audio and visual interactions besides text-based ones. Based on the pros of using synchronous interaction through Skype we can 
conclude that incorporating audio and visual interaction in collaborative writing systems would enhance the accuracy of academic writing.

- Synchronous e-feedback interaction is easier compared to the other modes with respect to the usefulness of and the motivation for using technology. However, asynchronous interaction is considered better than the other two interaction modes with respect to the technology acceptance model. This suggests that it will be useful to develop a strategy combining the benefits of these two interaction modes.

Improving the content structure and the language of academic writing is more complex than the mechanics of writing. Both the reviewer and the writer need to exchange their ideas on the manuscript to achieve an acceptable structure and language for their paper. Based on the participants' comments, it is not easy to figure out how to enhance various dimensions of academic writing. Sometimes the writer's personality affects the quality of discussion; sometimes the workload, for instance when the writer receives hundreds of emails every day, makes using asynchronous interaction more difficult than other types of interaction; sometimes the effort required to make extra arrangements, as in face-to-face meetings, adds more cognitive load on the writer. All these factors affect the improvement of a writer's academic writing.

In conclusion, academic writing is complex and different writers show different effects of feedback depending on the mode of interaction due to different preferences. Using synchronous e-feedback interaction can help participants to enhance their achievement motivation because it is interesting, easy to carry out, and can provide immediate feedback on participants' inquiries and questions. It has no psychological burden and is flexible in timing and workplace. It may be that because of the short duration of our study, no significant difference in improvement was observed between university students and researchers' critical thinking. To remedy this, a study over a longer period is necessary.

Our results suggest that as novice researchers have different needs than senior researchers, the effectiveness of academic writing systems and applications could be enhanced by incorporating a dynamic understanding of the researchers' needs. Providing both asynchronized and synchronized e-feedback along with face-to-face feedback can improve the quality of academic writing and achievement motivation, while using inappropriate e-feedback modes decreases the users' motivation to write academic publications. Inappropriate modes include complicated or ambiguous feedback without providing a chance for interpreting the received feedback, delays on urgently needed feedback, and feedback with negative emotions that decrease the accuracy of academic writing, writers' critical thinking abilities, and their achievement motivation toward academic writing.

We used non-parametric statistical tests for analyzing our data because our sample size was small. Hence there is a need to replicate the study with more participants. Also, the current study was conducted as one-to-one interaction between the reviewer and a participant (the writer), However, sometimes the reviewer in collaborative writing needs to provide feedback to more than one participant who works on the same project. Therefore, we need to conduct more studies to understand how various feedback interactions may affect the improvement of academic writing skills. Nonetheless, within one month the participants showed improvement in their critical thinking skills. We plan to conduct experiments of longer durations, with follow-up studies to better understand 
how various modes of interaction for providing the e-feedback affect the improvement of critical thinking skills.

\section{Author Statement}

The authors declare that there is no conflict of interest.

\section{Acknowledgements}

This research was supported in part by a grant from the Egyptian Ministry of Higher Education.

\section{ORCIID}

Mahmoud Mohamed Hussien Ahmed (iD https://orcid.org/0000-0003-3502-2886

Patricia S. McGahan (D) https://orcid.org/0000-0001-5147-5012

Bipin Indurkhya (iD https://orcid.org/0000-0002-3798-9209

Keiichi Kaneko (iD https://orcid.org/0000-0003-1790-4615

Masaki Nakagawa (D) https://orcid.org/0000-0001-7872-156X

\section{References}

Abrams, Z. I. (2003). The effect of synchronous and asynchronous CMC on oral performance in German. The Modern Language Journal, 87(2), 157-167.

Alexander, P. A. (2014). Thinking critically and analytically about critical-analytic thinking: An introduction. Educational Psychology Review, 26(4), 469-476.

Averkieva, L., Chayka, Y., \& Glushkov, S. (2015). Web quest as a tool for increasing students' motivation and critical thinking development. Procedia-Social and Behavioral Sciences, 206, 137-140.

Bailey, S. (2014). Academic writing: A handbook for international students. New York, NY: Routledge.

Basaran, B., \& Yalman, M. (2020). Examining university students' attitudes towards using web-conferencing systems in distance learning courses: A study on scale development and application. Knowledge Management \& E-Learning, 12(2), 209-230.

Bauer, C., Figl, K., Derntl, M., Beran, P. P., \& Kabicher, S. (2009). The student view on online peer reviews. In Proceedings of the 14th annual ACM SIGCSE Conference on Innovation and Technology in Computer Science Education (pp. 26-30).

Behrens, P. J. (1996). The Watson-Glaser critical thinking appraisal and academic performance of diploma school students. Journal of Nursing Education, 35(1), 34-36.

Bernard, R. M., Zhang, D., Abrami, P. C., Sicoly, F., Borokhovski, E., \& Surkes, M. A. (2008). Exploring the structure of the Watson-Glaser critical thinking appraisal: One scale or many subscales? Thinking Skills and Creativity, 3(1), 15-22.

Biber, D., Nekrasova, T., \& Horn, B. (2011). The effectiveness of feedback for L1-English and L2-writing development: A meta-analysis (TOEFL iBT ${ }^{\mathrm{TM}}$ Research Report: No. TOEFLiBT-14). Princeton, NJ: Educational Testing Service (ETS).

Boling, E. C., Hough, M., Krinsky, H., Saleem, H., \& Stevens, M. (2012). Cutting the 
distance in distance education: Perspectives on what promotes positive, online learning experiences. The Internet and Higher Education, 15(2), 118-126.

Borglin, G., \& Fagerström, C. (2012). Nursing students' understanding of critical thinking and appraisal and academic writing: A descriptive, qualitative study. Nurse Education in Practice, 12(6), 356-360.

Bouwmeester, R. A. M., de Kleijn, R. A. M., van den Berg, I. E. T., ten Cate, O. T. J., van Rijen, H. V. M., \& Westerveld, H. E. (2019). Flipping the medical classroom: Effect on workload, interactivity, motivation and retention of knowledge. Computers \& Education, 139, 118-128.

Carpenter, T. G., Brown, W. L., \& Hickman, R. C. (2004). Influences of online delivery on developmental writing outcomes. Journal of Developmental Education, 28(1), 1416.

Carpenter, J. P., Krutka, D. G., \& Kimmons, R. (2020). \#RemoteTeaching \& \#RemoteLearning: Educator Tweeting During the COVID-19 Pandemic. Journal of Technology and Teacher Education, 28(2), 151-159.

Carter, A. G., Creedy, D. K., \& Sidebotham, M. (2017). Critical thinking evaluation in reflective writing: Development and testing of Carter Assessment of Critical Thinking in Midwifery (Reflection). Midwifery, 54, 73-80.

Cha, Y., \& Park, L. E. (2010). An analysis of synchronous interaction and its influence on EFL writers' revisions. Multimedia Assisted Language Learning, 13(2), 9-36.

Chiang, A. C. C., \& Fung, I. P. W. (2004). Redesigning chat forum for critical thinking in a problem-based learning environment. The Internet and Higher Education, 7(4), 311-328.

Chiang, T. H. C., Yang, S. J. H., Huang, C. S. J., \& Liou, H.-H. (2014). Student motivation and achievement in learning English as a second language using second life. Knowledge Management \& E-Learning, 6(1), 1-17.

Demirel, M., \& Arslan Turan, B. (2010). The effects of problem based learning on achievement, attitude, metacognitive awareness and motivation. Hacettepe University Journal of Education, 38, 55-66.

Derish, P. A., Maa, J., Ascher, N. L., \& Harris, H. W. (2007). Enhancing the mission of academic surgery by promoting scientific writing skills. Journal of Surgical Research, 140(2), 177-183.

Dwyer, C. P., \& Walsh, A. (2020). An exploratory quantitative case study of critical thinking development through adult distance learning. Educational Technology Research and Development, 68, 17-35.

Ecarnot, F., Seronde, M. F., Chopard, R., Schiele, F., \& Meneveau, N. (2015). Writing a scientific article: A step-by-step guide for beginners. European Geriatric Medicine, 6(6), 573-579.

Filgona, J., Sakiyo, J., Gwany, D. M., \& Okoronka, A. U. (2020). Motivation in learning. Asian Journal of Education and Social Studies, 10(4), 16-37.

Glasman-Deal, H. (2010). Science research writing for non-native speakers of English. World Scientific Publishing.

Hall, S. (2017). Practise makes perfect: Developing critical thinking and writing skills in undergraduate science students. In Proceedings of the 3rd International Conference on Higher Education Advances (pp. 1044-1051).

Heift, T., \& Caws, C. (2000). Peer feedback in synchronous writing environments: A case study in French. Educational Technology \& Society, 3(3), 208-214.

Herbert, D. L., Coveney, J., Clarke, P., Graves, N., \& Barnett, A. G. (2014). The impact of funding deadlines on personal workloads, stress and family relationships: A qualitative study of Australian researchers. BMJ Open, 4(3): e004462.

Hermans, H. J. (1970). A questionnaire measure of achievement motivation. Journal of 
Applied Psychology, 54(4), 353-363.

Hrastinski, S. (2008). Asynchronous and synchronous e-learning. EDUCAUSE Quarterly, $31(4), 51-55$.

Hyland, F. (2011). The language learning potential of form-focused feedback on writing: Students' and teachers' perceptions. In R. M. Manchón (Ed.), Learning-to-Write and Writing-to-Learn in an Additional Language (pp. 159-179). Amsterdam, NLD: John Benjamins Publishing Company.

Jacob, S. M. (2012). Mathematical achievement and critical thinking skills in asynchronous discussion forums. Procedia-Social and Behavioral Sciences, 31, 800804.

Keh, C. L. (1990). Feedback in the writing process: A model and methods for implementation. ELT Journal, 44(4), 294-304.

Kew, S. N., \& Tasir, Z. (2021). Analysing students' cognitive engagement in e-learning discussion forums through content analysis. Knowledge Management \& E-Learning, 13(1), 39-57.

Kong, S. C. (2014). Developing information literacy and critical thinking skills through domain knowledge learning in digital classrooms: An experience of practicing flipped classroom strategy. Computers \& Education, 78, 160-173.

Lang, J. W. B., \& Fries, S. (2006). A revised 10-item version of the achievement motives scale. European Journal of Psychological Assessment, 22(3), 216-224.

Liao, H. A., Ferdenzi, A. C., \& Edlin, M. (2012). Motivation, self-regulated learning efficacy, and academic achievement among international and domestic students at an urban community college: A comparison. The Community College Enterprise, 18(2), 9-38.

McClelland, D. (2005). Achievement motivation theory. In J. B. Miner (Ed.), Organizational Behavior 1: Essential Theories of Motivation and Leadership (pp. 4660). New York, NY: M.E. Sharpe, INC.

McClelland, D. C. (1961). The achieving society. New York, NY: Free Press.

Moriarty, M. F. (1997). Writing science through critical thinking. Boston, MA: Jones \& Bartlett Learning.

Murphy, E., Rodríguez-Manzanares, M. A., \& Barbour, M. (2011). Asynchronous and synchronous online teaching: Perspectives of Canadian high school distance education teachers. British Journal of Educational Technology, 42(4), 583-591.

Muthmainnah, N. (2019). Optimizing critical thinking skill through peer editing technique in teaching writing. ELTIN Journal, 7(1), 1-7.

Newman, D. R., Johnson, C., Webb, B., \& Cochrane, C. (1997). Evaluating the quality of learning in computer supported co-operative learning. Journal of the American Society for Information Science, 48(6), 484-495.

Osborne, D. M., Byrne, J. H., Massey, D. L., \& Johnston, A. N. B. (2018). Use of online asynchronous discussion boards to engage students, enhance critical thinking, and foster staff-student/student-student collaboration: A mixed method study. Nurse Education Today, 70, 40-46.

Papi, M., Bondarenko, A. V., Wawire, B., Jiang, C., \& Zhou, S. (2020). Feedbackseeking behavior in second language writing: Motivational mechanisms. Reading and Writing, 33(2), 485-505.

Paul, R. P., \& Elder, L. (2002). Critical thinking: Tools for taking charge of your professional and personal life. Upper Saddle River, NJ: Pearson Education Inc.

Preiss, D. D., Castillo, J. C., Flotts, P., \& San Martín, E. (2013). Assessment of argumentative writing and critical thinking in higher education: Educational correlates and gender differences. Learning and Individual Differences, 28, 193-203.

Razi, S. (2015). Development of a rubric to assess academic writing incorporating plagiarism detectors. SAGE Open, 5(2). doi: 10.1177/2158244015590162 
Roblyer, M. D., Freeman, J., Donaldson, M. B., \& Maddox, M. (2007). A comparison of outcomes of virtual school courses offered in synchronous and asynchronous formats. The Internet and Higher Education, 10(4), 261-268.

Sachs, J. (2002). A path model for students' attitude to writing a thesis. Scandinavian Journal of Educational Research, 46(1), 99-108.

Scherer, R., Siddiq, F., \& Tondeur, J. (2019). The technology acceptance model (TAM): A meta-analytic structural equation modeling approach to explaining teachers' adoption of digital technology in education. Computers \& Education, 128, 13-35.

Schillings, M., Roebertsen, H., Savelberg, H., van Dijk, A., \& Dolmans, D. (2021). Improving the understanding of written peer feedback through face-to-face peer dialogue: Students' perspective. Higher Education Research \& Development, 40(5), 1100-1116.

Stein, D. S., Wanstreet, C. E., Slagle, P., Trinko, L. A., \& Lutz, M. (2013). From 'hello' to higher-order thinking: The effect of coaching and feedback on online chats. The Internet and Higher Education, 16, 78-84.

Sun, N., Yuan, C. W. T., Rosson, M. B., Wu, Y., \& Carroll, J. M. (2017). Critical thinking in collaboration: Talk less, perceive more. In Proceedings of the $2017 \mathrm{CHI}$ Conference Extended Abstracts on Human Factors in Computing Systems (pp. 2944 2950). ACM.

Swales, J. M., \& Feak, C. B. (2004). Academic writing for graduate students: Essential tasks and skills (Vol.1). University of Michigan Press.

Swales, J. M., \& Feak, C. B. (2012). Academic writing for graduate students: Essential tasks and skills (3rd ed.). University of Michigan Press.

Tallent-Runnels, M. K., Cooper, S., Lan, W. Y., Thomas, J. A., \& Busby, C. (2005). How to teach online: What the research says. Distance Learning, 2(1), 21-27.

Thompson, S. D., Martin, L., Richards, L., \& Branson, D. (2003). Assessing critical thinking and problem solving using a web-based curriculum for students. The Internet and Higher Education, 6(2), 185-191.

VandeWalle, D. (2003). A goal orientation model of feedback-seeking behavior. Human Resource Management Review, 13(4), 581-604.

Waller, L., \& Papi, M. (2017). Motivation and feedback: How implicit theories of intelligence predict L2 writers' motivation and feedback orientation. Journal of Second Language Writing, 35, 54-65.

Wallwork, A. (2016). English for writing research papers (2nd ed.). New York, NY: Springer.

Weldon, A., Ma, W. W. K., Ho, I. M. K., \& Li, E. (2021). Online learning during a global pandemic: Perceived benefits and issues in higher education. Knowledge Management \& E-Learning, 13(2), 161-181.

Zeynali, S., Pishghadam, R., \& Fatemi, A. H. (2019). Identifying the motivational and demotivational factors influencing students' academic achievements in language education. Learning and Motivation, 68: 101598.

Zhang, K., \& Toker, S. (2011). Stimulating critical thinking in a virtual learning community with instructor moderations and peer reviews. Knowledge Management \& E-Learning, 3(4), 534-547.

Zhang, Z. J., Zhang, C. L., Zhang, X. G., Liu, X. M., Zhang, H., Wang, J., \& Liu, S. (2015). Relationship between self-efficacy beliefs and achievement motivation in student nurses. Chinese Nursing Research, 2(2/3), 67-70. 